\title{
Subject Clitics in Microcontact: A Case Study from Heritage Friulian in Argentina and Brazil
}

\author{
Alberto Frasson \\ PhD Candidate, Utrecht Institute of Linguistics отs, Utrecht University \\ Utrecht, The Netherlands \\ a.frasson@uu.nl \\ Roberta D'Alessandro \\ Professor, Utrecht Institute of Linguistics OTs, Utrecht University, \\ Utrecht, The Netherlands \\ r.dalessandro@uu.nl \\ Brechje van Osch \\ Postdoctoral Researcher, Department of Language and Culture UiT, \\ The Arctic University of Norway, Tromsø, Norway \\ brechje.a.osch@uit.no
}

\begin{abstract}
In this paper we present data from first generation immigrants $(\mathrm{G} 1)$ and second and third generation heritage speakers of Friulian, a Rhaeto-Romance language spoken in North-Eastern Italy and also found in Argentina and Brazil. The target phenomenon is subject clitics (SCLS). We show that SCLs in heritage Friulian are in a process of being reanalyzed from being agreement markers to pronouns. While SCLs are obligatory in Friulian as spoken in Italy, they are often dropped in heritage Friulian in Argentina and Brazil; this phenomenon, we argue, needs to be interpreted as the drop of pronominal subjects, and not of agreement-like SCLs. We also demonstrate that the use of SCLs (reanalyzed as pronominal subjects) is conditioned both by grammatical factors (it happens more in some grammatical persons than in others) and by discourse factors (they are used more in the case of a continuation topic than in other topicalization contexts). This means that in heritage Friulian, discourse constraints on the expression of subjects are not being lost or weakened; in fact, against the general grammaticalization trend of pronominal forms, new discourse constraints are introduced.
\end{abstract}




\section{Keywords}

heritage language - subject clitics - null subjects - topicality - interfaces

\section{Introduction}

This article is concerned with language change in contact, in particular in situations of unbalanced bilingualism, such as the case of first-generation immigrants and heritage speakers (HS s).

The ever-growing field of heritage language studies has thus far revealed several generalizations regarding heritage grammars (i.e., Benmamoun, Montrul \& Polinsky, 2013; Montrul, 2016; Polinsky, 2018). While change can be detected in all domains of grammar, certain domains may be particularly vulnerable. Already at the beginning of this century, various researchers observed that phenomena pertaining to the $\mathrm{C}$-domain are vulnerable in bilingual acquisition (Hulk \& Müller, 200o). This observation ultimately led to the formulation of the Interface Hypothesis (Sorace \& Filiaci, 2006; Sorace, 2011), which claims that constructions in which syntax interacts with other language modules, such as discourse and pragmatics, are particularly vulnerable in bilingual populations.

Probably the most described phenomenon connected to the Interface Hypothesis has been the expression and the interpretation of subjects in prodrop languages in contact with non-pro-drop languages. Several studies on bilinguals whose weaker language is pro-drop have shown that, while these speakers have some command of the syntactic constraints related to the distribution of null subjects, they tend to overuse overt subjects in discourse contexts where null subjects are expected (e.g., Sorace \& Filiaci, 2006; Sorace \& Serratrice, 2009).

Tsimpli et al. (2004) and Sorace et al. (2009), working on Greek-English and Italian-English bilinguals respectively, attribute this to bilingual speakers opting for the simpler system: while the English system offers only one option, i.e. overt subjects, Greek and Italian systems require the mastery of a more complex interaction between grammatical and discourse factors in order to select the correct, or more appropriate, form of the subject (overt or null). An increasing number of studies showing that heritage speakers do not have complete mastery of pro-drop has been released in the last few years (Carvalho \& Bessett, 2015; Dubinina \& Polinsky, 2013; Keating, VanPatten \& Jegerski, 2011; Montrul, 2004, 2008). On the other hand, some studies showed no effect of language contact on the realization and interpretation of null subjects (Flores \& Rinke, 202O; Nagy et al., 2011; Rinke \& Flores, 2018). In this article, we focus on the expression of subject clitics (SCLS) in heritage Friulian, 
a Rhaeto-Romance language originally spoken in North-Eastern Italy and also found in Argentina and Brazil. Following the methodology applied in Polinsky (2018), we present data from four first generation immigrants ( $\mathrm{G} 1$, age of arrival of 10 years or older) and 12 second and third generation heritage speakers (HS s) of Friulian.

While SCLs are obligatory in Friulian as spoken in Italy, we will show that they are often dropped in heritage Friulian in Argentina and Brazil. On the basis of a number of considerations, we will argue that this phenomenon needs to be interpreted as the drop of pronominal subjects, and not of agreement-like SCLS. In other words, in the immigrant varieties, the syntactic status of these SCLS has changed. We also demonstrate that the use of SCLs, reanalyzed as pronominal subjects, is conditioned both by grammatical factors (they are used more in some persons than in others) and by discourse factors (they are used more in the case of topic continuation than in other topicalization contexts). This means that it is not the case that discourse constraints on the expression of subjects are being lost or weakened in these heritage varieties; in fact, new discourse constraints are introduced with respect to the described variety spoken in Italy. These constraints are also found in other pro-drop languages, and as such are not new. They are, however, new for this specific variety.

Before discussing the data and the issue, a premise is in order. The data of heritage Friulian were collected on fieldwork, through interviews with G1 and HS of Friulian. Finding these speakers was not an easy task, both because most G1 and Hs have abandoned Friulian altogether, and because the Friulian community is rather scattered. Moreover, G1 speakers are rather elderly, which made it impossible to collect abundant data or ask them to perform a large number of tasks.

When G1 of Friulian left Italy they were mostly monolingual and therefore not fluent in Italian. In Italy, around the 195os, Friulian entered into systematic contact with Italian. The version of Friulian that G1 emigrants speak stems, however, from a pre-contact situation. To ascertain the changes that emerged due to contact between Friulian and Spanish and Portuguese we would need to compare heritage Friulian with monolingual speakers of Friulian. These monolinguals would have to speak the language that was spoken in the 1950s before it entered in contact with Italian. These monolingual speakers do not exist: Friulian is spoken nowadays only in a bilingual situation; furthermore, it has changed since the time when these monolingual speakers left because of intensive contact with Italian.

Although we are aware that the question of how contact with Italian affected the grammar of modern Friulian is important in the analysis of change in contact, the issue will not be discussed in this article. In the present study, we 
relied on grammars from the 1950s and '6os, where the variety spoken by G1 Friulian was documented.

The Friulian clitic system that we consider in the rest of the article is therefore that which is found in the grammars describing Friulian at the beginning/ half of previous century, which is the time when G1 speakers left Italy to emigrate to Argentina and Brazil. The SCL system described in these grammars (Della Porta, 1922) is identical to that described in more recent studies on the syntax of Friulian (Benincà, 2014, 2015; Benincà \& Vanelli, 2016). Some minor changes in the phonetics of SCLs do not affect the system that we are examining here.

Given the absence of a proper baseline variety, the reference to the system presented in these studies is the only way we have to show that change happened. Despite this seemingly restricted set of data, we believe that documenting a variety that is close to extinction is of great importance. Furthermore, our aim is to describe the syntax of SCLs in heritage Friulian; given that the speakers' grammars are rather consistent, we take this sample as being representative enough to draw some generalizations and attempt an analysis.

This article is organized as follows. In the next section we discuss the grammatical and discourse properties of pro-drop, followed by an overview of previous research concerning this phenomenon in bilingual populations. Sections 3 and 4 illustrate the pronominal systems in Friulian and in the contact languages, Argentinian Spanish and Brazilian Portuguese, respectively. In Section 5 our data collection is presented, followed by the results in Section 6; Section 7 offers an analysis of null subjects in heritage Friulian. Section 8 contains our conclusions.

2

Pro-Drop

\subsection{Why Pro-Drop Is Called Pro-Drop}

Null subjecthood is the phenomenon whereby some languages can leave the overt subject of a clause unexpressed. Null subject languages are usually referred to as pro-drop as it is assumed that the element left out is pronominal. The reason for this assumption is the observation that full DP s usually introduce new referents in a clause, while pronouns do not always (if we leave aside ostension, pronouns must refer to an element already mentioned in the discourse). In well-behaved pro-drop languages, the subject can be left out when referring to an element already present in the discourse, usually a topic (Frascarelli, 2007; Frascarelli \& Hinterhölzl, 2007; Kwon \& Sturt, 2012; 
Jimenez-Fernández, 2016; Frascarelli \& Jimenez-Fernández, 2019; Sorace et al., 2009; Sorace \& Serratrice, 2009).

In (1), the pro subject is interpreted as being co-referential with the subject of the preceding clause. In (2), an overt pronoun does not necessarily corefer with the subject of the preceding clause, but it can. The postverbal position of the pronoun is more felicitous because it bears a contrastive focus, which is more consistent with the use of an overt pronoun. In (3), the repetition of the full DP can only be licensed if the two DP s have different referents. In particular, the post-verbal, focused position is ruled out with a co-referential reading.

(1) Il professore ${ }_{i}$ è entrato. pro ${ }_{i}$ ha iniziato a parlare the professor is entered pro has started to talk "The professor entered. He started to talk"

(2) Il professore ${ }_{\mathrm{i}}$ è entrato. Mentre (lui $\left.\mathrm{i}_{\mathrm{i}, \mathrm{j}}\right)$ iniziava a parlare $\left(\operatorname{lui}_{\mathrm{i}, \mathrm{j}}\right)$, the professor is entered while he started to talk he una ragazza si è alzata di scatto a girl is stood suddenly

"The professor entered. When he started to talk, a girl suddenly stood up"

(3) Il professore ${ }_{i}$ è entrato. (Il professore ??i,j )

the professor is entered the professor

ha iniziato a parlare (il professore $*_{i, j}$ )

has started to talk the professor

"The professor entered. The professor started to talk"

These sorts of considerations caused linguists to postulate that the silent element, in sentences like (1), is a pronoun and not an overt DP. Notably, the observation that pro is a pronominal element is taken into account by Rizzi (1982) when formulating the null subject parameter. His formulation is the following:

a. INFL can be specified [+pronoun]

b. INFL which is [+pronoun] can be referential.

Only a pronominal INFL can license a null subject. (Rizzi, 1982, p. 143)

Not all pro-drop languages have the same distribution of pro. Some languages are radically pro-drop, others are subject pro drop for all persons, others can drop the pronominal subject only for some persons (see Holmberg, 2005, and D'Alessandro, 2015 for an overview of the distribution of pro). 


\subsection{Conditions on the Interpretation of Pro}

Regarding the interpretation of pro, it has been shown that, in case of multiple possible antecedents, pro tends to refer to the sentential subject (Calabrese, 1986; Carminati, 2002), while overt pronouns tend to refer to lower arguments. As an example, consider (4), from Carminati (2002):
(4) Marta scriveva frequentemente
a Piera quando pro / lei era
Marta $_{i}$ wrote frequently
to Piera $_{j}$ when pro $_{i, j} /$ she $_{i / j}$ was
negli Stati Uniti
in the US
"Marta frequently wrote to Piera when she was in the US" (83).

While Italian syntax allows pro to potentially corefer with both antecedents, Marta and Piera, Carminati (2002) shows through a number of experiments that native speakers of Italian prefer the interpretation according to which pro refers to the item in Spec, TP (i.e., in the canonical sentential subject position). The overt pronoun selects a lower antecedent instead (in this case, Piera). Carminati's work sets an important milestone in defining the conditions for pro licensing and highlights that null subjects involve more than just syntax.

That the use of pro is not only determined by syntax is shown by several studies, most notably those put forward by Sorace et al. regarding the processing and interpretation of pro, ${ }^{1}$ and those proposed by Frascarelli (2007), Jiménez-Fernández (2016), Miyagawa (2017) and many others. Sorace's work focuses on L2 acquisition and bilingualism, while Miyagawa, Frascarelli and Jiménez-Fernández focus on pro in monolingual varieties. The conclusion they all reach is, however, rather similar: topicality plays an important role in licensing pro. The pronoun is more likely to be overtly expressed in sentences where there is a shift in topic with respect to the previous discourse. As an example, compare (5) and (6) from Spanish (Montrul, 2004; p. 128):

(5) Pepe no vino hoy a trabajar. *Pepe / ?Él / pro estará enfermo. Pepe not came today to work. Pepe / he / prowill be sick. "Pepe did not come to work today. He must be sick."

1 Sorace (2011) and her colleagues' works focus mostly on the processing aspects related to the discourse constraints on pronouns, although she does not rule out that syntactic representation may also be involved (Sorace, 2011). 

(6) Hoy no fui a trabajar. Pepe / él / *pro pensó que estaba today no went.1sG to work Pepe / he / pro thought that I was enferma
sick
"Today I did not go to work. Pepe/he thought I was sick."

(5) is an example of topic continuation: the topic of the second sentence is the same as in the first sentence, which makes a null subject the most felicitous option. In (6), there is a topic shift: the subject changes from the ist person to a 3rd person, thus requiring an overt pronoun (or a full DP).

\subsection{Pro-Drop in Contact}

The realization of null and overt subjects in pro-drop languages has been one of the main topics in studies on bilingualism, as mentioned above. Several studies have shown that bilingual populations whose weaker language is a null-subject one tend to overgeneralize overt subjects to pragmatically infelicitous contexts. This tendency is attested in bilingual children (e.g., Sorace et al., 2009), adult L2 learners (e.g., Sorace \& Filiaci, 2006), L1 attriters (e.g., Tsimpli et al., 2004) and HSs (e.g., Montrul, 2004). This is especially true when one of the languages is not a pro-drop language, like English.

In contrast, some studies on the expression of the subject when two Romance languages are in contact have shown that null subjects may be easily handled by bilingual speakers (Carvalho \& Child, 2011; De Souza, Chaves, \& Simioni, 2018). In particular, the varieties of Uruguayan Spanish and Portuguese spoken on the border with Brazil display rates of null subjects that pattern with canonical pro-drop languages (like Spanish) rather than with non-pro-drop or partial pro-drop languages (like Brazilian Portuguese).

These data contrast with other studies that demonstrate an overextension of overt subject pronouns even when both languages are pro-drop (Bini, 1993 and Sorace \& Serratrice, 2009, for Italian-Spanish; Margaza \& Bel, 2006, and Lozano, 2006 for Greek-Spanish; Guido Mendes \& Iribarren, 2007 for Brazilian Portuguese and Spanish). However, as noted by Filiaci, Sorace and Carreiras (2014), it may be the case that the division of labor between null and overt pronouns in the two null-subject varieties in contact is not identical.

The literature also reports a so-called person effect. First person singular seems to be the most frequent overt pronominal subject, even in cases where it does not serve a pragmatic function like, for instance, indicating contrastive focus or a shift in topic. This person effect has been attested both in monolingual acquisition (Serratrice, 2005 for Italian children) and bilingual 
acquisition (Pinto, 2006 for Dutch-Italian children), as well as in H s s (Schmitz, Di Venanzio, and Scherger, 2016 for Italian and Spanish Hs s in Germany).

\section{Pronominal, Clitic, and Null Subjects in Friulian}

Friulian is particularly interesting as far as pro-drop is concerned, as it has two series of subject pronouns, one tonic one the other clitic (see Benincà, 2014, 2015; Benincà \& Vanelli, 2016; Poletto, 1993, 2000).

Friulian tonic pronouns are strong pronouns, according to the traditional tripartite model initially proposed by Cardinaletti and Starke (1999). On a par with their Italian or Spanish counterparts, Friulian tonic pronouns are stressbearing elements that can appear in isolation or can be coordinated. Friulian has generally been analyzed as a canonical null subject language, in that strong pronouns are not obligatory and are normally realized only when they serve some discourse function. However, Friulian differs from canonical null subject languages like Italian in that it has an additional set of obligatory SCLs. These are not real pronominal elements: they are inflectional heads, on a par with verbal agreement endings. These sCLs are also found in other varieties spoken in northern Italy, such as Venetan (Benincà, 1994) and Trentino (Brandi \& Cordin, 1989; see also: Poletto, 1993, 200o; Rizzi, 1986). The situation is illustrated in (7):

(7) Friulian

Jo o feveli furlan.

I I.SCL speak Friulian

'I speak Friulian.'

In example (7) we see that the overt subject and the SCL co-occur; this is possible because SCLs are inflectional elements and do not function as subjects. Unlike pronouns, they also need to be realized in both conjuncts in coordinated structures, as shown in (8), and do not allow for non-clitic material to be inserted between them and their verbal host, as shown in (9).

(8) Friulian

Al mangje e *(al) bef.

he.SCL eats and he.SCL drinks.

'He is eating and drinking.' 

(9) Al (*simpri) diseve (simpri) cussì. he.SCL always said always like this 'He always said this.'

Furthermore, SCLs' paradigms can be defective, while pronominal ones never are.

These conditions to ascertain the nature of SCLs were first identified by Rizzi (1986) for northern Italo-Romance varieties. More specific studies on Friulian (Benincà and Vanelli, 2015; Gaglia, 2012) show that the system of this language is particularly uniform: SCLs are present with finite verbs in all persons and are realized in all syntactic contexts. As a general rule, if a language has a SCL for a specific person, it must use it: SCLs are not optional.

The only exception is instantiated by clitic clusters: SCLS are not realized when they appear in a cluster (including negation, direct and indirect object, impersonal and reflexive ${ }^{2}$ ), as illustrated in (10).

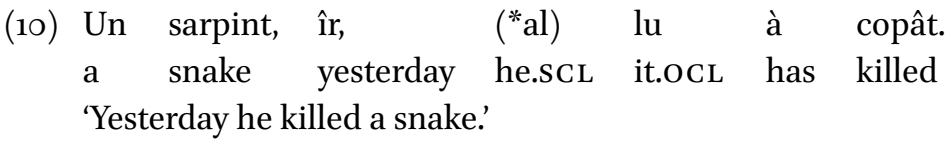

The conditions under which we expect a SCL are quite easily identifiable, which makes Friulian a good candidate for the analysis of change in contact. The complete paradigm of subject pronouns and clitics in Friulian is outlined in Table 1.

2 There are two exceptions to this restriction in Friulian subject clitics:

i) second person singular is generally immune to this restriction, as the subject clitic $t u$ is realized even when it cooccurs with other pronominal clitics and with negation;

ii) the subject clitic $a$, unlike other subject clitics, in some varieties appears before negation and its realization is not affected by the cooccurrence of other clitics; according to Poletto (2000) $a$ is not an agreement clitic, but rather a deictic clitic located in CP, which would explain its idiosyncratic behavior; other works (see in particular Casalicchio \& Masutti, 2015) provide evidence that the clitic $a$ in Friulian is a real agreement marker, as shown by its ability to doubles lexical subjects and is repeated in both conjuncts in coordinated structures. 
TABLE 1 The paradigms of Friulian tonic and clitic subject pronouns

\begin{tabular}{lcccc}
\hline \multicolumn{2}{c}{ Singular } & \multicolumn{2}{c}{ Plural } \\
& Tonic & Clitic & Tonic & Clitic \\
\hline 1 & jo & i / o & on / noaltris & i /o \\
2 & tu & tu & vô / vualtris & i / o \\
3 & M: lui & M: al & lôr & a / e \\
& F:je & F: e / a & & \\
\hline
\end{tabular}

Note furthermore that Friulian varieties display considerable microvariation in the paradigm of SCLs. In the case of 1st person singular and plural, 2nd person plural and 3 rd person singular and plural, allomorphy exists in different dialects of Friulian, which is observable in Table $1 .^{3}$

As far as pro-drop is concerned, Friulian is a fully-fledged null subject language: full subjects can be dropped in the same structural and pragmatic conditions that determine subject drop in Italian or Spanish. Recall that Friulian SCLs are inflectional elements, and therefore their occurrence in a clause does not amount to saying that this is a non-null subject clause.

Previous research (Frasson, in press) on HSs of Venetan, a northern Italo-Romance variety, has shown that SCLs tend to be reanalyzed as weak pronouns, in the terms of Cardinaletti and Starke (1999). In this system, pronouns are divided into three classes: a strong one, a weak one and a clitic one. The trigger of the asymmetries that emerge among classes is structural deficiency: the more deficient a pronoun, the fewer phonological, morphological, syntactic and semantic features it realizes. While we cannot provide conclusive evidence that the same reanalysis from clitics to weak pronouns is also taking place in heritage Friulian, in this article we show that Friulian SCLs do display pronominal behavior, since they are not licensed in the context of doubling of a lexical or pronominal subject except when these are clearly topicalized (Section 6.1, Table 4); besides, scls can be dropped in the second conjunct in coordinated structures (Section 6,1, Table 6) and the restriction on their

3 In the varieties we consider, allomorphs are used in free variation. Therefore we do not further explore the differences between them. See Poletto (2000) for an analysis of different types of SCLs in a cartographic approach. 
appearance in clitic clusters is violable ${ }^{4}$ (Section 6.1, Table 5). This syntactic behavior, in Rizzi's (1986) terms, is typical of pronouns, not of clitics. We therefore take these findings to indicate that they are in a process of reanalysis, from inflectional to pronominal elements. In the next section we present some relevant data on null subjects in Argentinian Spanish and Brazilian Portuguese, the two contact varieties, that may affect the system of subject pronouns of heritage Friulian.

\section{$4 \quad$ Null Subjects in Argentinian Spanish and Brazilian Portuguese}

The varieties of Friulian under analysis are spoken in Argentina and Brazil, where they underwent extensive contact with Spanish and Portuguese, respectively. The local varieties of Portuguese and Spanish are relevant for our study, in that they represent the dominant contact languages for most of the speakers. Therefore, their status with respect to null subjecthood, the nature of pro and the conditions on its realization presented in section 2.1, are crucial to define the role of contact in shaping the change in heritage Friulian.

Brazilian Portuguese has been analyzed as a partial-pro-drop language. ${ }^{5}$ Based on the analysis of a corpus of written texts, Duarte (2000) shows that 2nd person singular subject pronouns are much more frequent in Brazilian Portuguese (9o\% of the occurrences) than in European Portuguese $(24 \%)$. Similarly, Barbosa et al. (2005) show that spoken Brazilian Portuguese displays a higher number of overt pronominal subjects than European Portuguese and argue that might be related to the fact that verbal morphology in Brazilian Portuguese is reduced. For this reason, an overtly realized subject must appear in Spec-TP in Brazilian Portuguese. In spoken varieties, such a pronoun is generally a weak, phonologically reduced counterpart of the strong pronoun, as illustrated in (11), the structure of which is exemplified in (12). As noted by Kato (1999), when the strong pronoun is found in a left dislocated position inside the complementizer field, a weak pronoun can double it.

4 For a discussion of cases of subject clitic drop in Friulian, see also Pescarini and Calabrese (2014), who analyze the phenomenon in terms of fission. Gaglia (2010, 2012), on the other hand, proposes an optimal-theoretical perspective.

5 Our study focusses on the realization of the subject in main clauses. Specifically for Brazilian Portuguese, it has been shown that subject realization in embedded clauses is different. See Duarte $(1993,1995)$ and Rodrigues (2004) for a clear picture of the restrictions on subject drop in Brazilian Portuguese. 
(11) Spoken Brazilian Portuguese

Você, esta canção, (cê) canta -a lindamente.

you this song you sing.2sG it beautifully

'You sing this song beautifully.'

(12) $[$ TopP Você [TP cê [T canta] [vP ...]]]

The doubling of DP subjects through (weak) pronouns seems to be particularly common in Riograndense Brazilian Portuguese, the colloquial variety spoken in Rio Grande do Sul, the area where the data for this study were collected. To be completely sure of the status of the contact language with respect to null subjects, we interviewed one monolingual Brazilian Portuguese speaker in Caxias do Sul and one in Bento Gonçalves. A preliminary analysis of spontaneous speech shows that lexical DP s subjects realized by these speakers are generally doubled with an agreeing pronominal element, as shown in (13):

(13) Riograndense Brazilian Portuguese

O gaucho ele fala "buenas".

the gaucho he speaks buenas

'A gaucho would say "buenas."'

The doubling seems to be restricted to DP subjects: there are no cases of phonologically reduced pronouns doubling tonic pronouns.

As for Argentinian Spanish, we rely on the research that has been conducted on the expression of the subject in the Rioplatense variety. In the literature on Spanish dialects (see in particular Silva-Corvalán, 2001), the Rioplatense variety is described as a pro-drop language, in which null subjects are generally favored. The only notable difference between Rioplatense and European Spanish regards the realization of the 2nd person singular subject pronoun with a non-specific referent or in its impersonal use; in this case Silva-Corvalán (2001) shows that the overt realization of the pronoun is much more frequent in Rioplatense ( $55 \%$ of the total occurrences of 2nd person singular) than in European Spanish (19\%). However, when the referent is specific, Rioplatense Spanish does not exhibit a preference for the overt pronoun.

Some of the points we highlighted here will become relevant in the discussion of the heritage Friulian data: the two contact languages have a different distribution of pro. As a matter of fact, the conditions under which a null subject is accepted in the contact language seems to play a role in determining the realization of a pronominal subject as an overt or a null element in heritage 
Friulian. Before moving to the presentation of our results, we introduce some methodological notes.

The data used in this study were collected in March-April 2019 in Argentina (Buenos Aires and Colonia Caroya) and Brazil (Bento Gonçalves and Ivorà). The interviews were carried out by two interviewers in Argentina and Brazil. The tasks, as well as the instructions, were pre-recorded in Friulian by a native speaker of the language in order to avoid prompting the speaker for the contact language. These stimuli in Friulian were accepted as perfectly comprehensible, and accepted by the speakers without any objection. If the speaker needed extra information, it was provided in Spanish or Portuguese, i.e., in the contact language. All interviews were recorded and subsequently transcribed.

\subsection{Participants}

Our study involves 9 Friulian speakers in Argentina and 7 in Brazil, for a total of 16 speakers ( 4 females, 12 males); the speakers' ages range from 57 to 93 years. While we are aware that this number of speakers is low for an experiment, we still believe this is a good representative sample. First, the number of speakers who are alive at the moment and who still speak the language is extremely low: Friulian in Southern America is an endangered language. It is not possible to provide a total number of Friulian speakers in Argentina and Brazil at the moment, as there may be recent emigrants as well as many heritage Friulians who do not speak the language.

As stated in the introduction, while this situation is far from optimal for drawing generalizations, this study is mainly qualitative in nature. We believe that these varieties, though underrepresented, need to be documented before their total extinction, and that syntactic phenomena are worth investigating whether they are present in a population of 2 million or 20 speakers.

All the speakers of Friulian we interviewed are native speakers but are dominant in the contact language (Argentinian Spanish or Brazilian Portuguese). All Brazilian informants are third generation HS s born in remote areas of the state of Rio Grande do Sul; five Argentinian speakers are second generation Hs s born and raised in Buenos Aires, while the remaining four speakers were born in Italy and moved to different cities in Argentina when they were respectively 18, 14, 14 and 10 years old. The general tendency in both countries is to use the contact language in the vast majority of cases; speakers use Friulian 
only at home or with other Friulian speakers. This is particularly evident in the Friulian communities of Brazil, which are still quite isolated from the bigger Portuguese-majority speaking cities. In Argentina, Friulian always alternates with Spanish, even among members of the community. Other potentially relevant differences between the Friulian communities in Argentina and Brazil regard their level of education and knowledge of other languages. All the participants in Argentina also speak Italian (G1 immigrants are bilingual Friulian-Italian speakers and have learned Spanish when they moved to Argentina; HSs are bilingual Friulian-Spanish speakers and have learned Italian as a second language in Argentina); besides, four participants have a university degree, four participants have a high school degree, and only one participant only completed primary school. On the other hand, all participants in Brazil are Friulian-Portuguese bilingual speakers and were never exposed to Italian; five participants finished primary school, one participant attended the first two years of primary school and only one participant has a high school degree. ${ }^{6}$ The participants' details are summarized in Table 2.

TABLE 2 Sociolinguistic information on the participants

\begin{tabular}{|c|c|c|c|c|c|c|}
\hline & Country & City & Generation & Age & Gender & Education \\
\hline 1 & Argentina & Colonia Caroya & G1 (AOA: 14) & 79 & $\mathrm{~F}$ & High school \\
\hline 2 & Argentina & Buenos Aires & G1 (AOA: 14) & 86 & M & University \\
\hline 3 & Argentina & Buenos Aires & G1 (AOA: 18) & 84 & M & University \\
\hline 4 & Argentina & Buenos Aires & G1 (AOA: 10) & 73 & M & High school \\
\hline 5 & Argentina & Buenos Aires & $\begin{array}{l}\text { HS, second } \\
\text { generation }\end{array}$ & 57 & $\mathrm{~F}$ & High school \\
\hline 6 & Argentina & Buenos Aires & $\begin{array}{l}\text { HS, second } \\
\text { generation }\end{array}$ & 62 & $\mathrm{~F}$ & Primary school \\
\hline 7 & Argentina & Buenos Aires & $\begin{array}{l}\text { HS, second } \\
\text { generation }\end{array}$ & $5^{8}$ & M & University \\
\hline 8 & Argentina & Buenos Aires & $\begin{array}{l}\text { Hs, second } \\
\text { generation }\end{array}$ & 60 & M & University \\
\hline 9 & Argentina & Buenos Aires & $\begin{array}{l}\text { HS, second } \\
\text { generation }\end{array}$ & 78 & M & High school \\
\hline 10 & Brazil & Ivorà & $\begin{array}{l}\text { Hs, third } \\
\text { generation }\end{array}$ & $5^{\circ}$ & M & Primary school \\
\hline
\end{tabular}

6 We did not notice any differences in this speaker's knowledge and production of the language compared to the rest of the speakers. 
TABLE 2 Sociolinguistic information on the participants (cont.)

\begin{tabular}{|c|c|c|c|c|c|c|}
\hline & Country & City & Generation & Age & Gender & Education \\
\hline 11 & Brazil & $\begin{array}{l}\text { Bento } \\
\text { Gonçalves }\end{array}$ & $\begin{array}{l}\text { HS, third } \\
\text { generation }\end{array}$ & 76 & M & Primary school \\
\hline 12 & Brazil & Ivorà & $\begin{array}{l}\text { Hs, third } \\
\text { generation }\end{array}$ & 80 & M & Primary school \\
\hline 13 & Brazil & Ivorà & $\begin{array}{l}\text { Hs, third } \\
\text { generation }\end{array}$ & 65 & M & Primary school \\
\hline 14 & Brazil & Ivorà & $\begin{array}{l}\text { HS, third } \\
\text { generation }\end{array}$ & 66 & M & Primary school \\
\hline 15 & Brazil & Ivorà & $\begin{array}{l}\text { HS, third } \\
\text { generation }\end{array}$ & 93 & M & Primary school \\
\hline 16 & Brazil & Ivorà & $\begin{array}{l}\text { HS, third } \\
\text { generation }\end{array}$ & 54 & M & High school \\
\hline
\end{tabular}

While we are well aware of the speaker pool's non-homogeneity, we remind the reader that finding HSs of a non-standard variety in Brazil and Argentina is a difficult enterprise, as stated above. Furthermore, we take the convergence of data that were collected in different areas and from speakers with a variety of profiles as a sign that the change at issue is not exceptional, but rather the result of contact. Moreover, as we will show, the contact language seems to play a role in determining the output of change.

\subsection{Tasks and Materials}

At the beginning, a sociolinguistic questionnaire was proposed to all informants to obtain information on their background, including the degree and quality of their exposure to Friulian and to the contact languages, their language dominance, their education and family situation. Two tasks followed the sociolinguistic questionnaire: a forced-choice task and a spontaneous production task. Not all participants carried out both tasks: it was not possible to use audio stimuli with some of our elderly informants. Ten participants carried out both tasks; for 2 participants in Brazil only spontaneous production data were collected, while for 3 participants in Argentina only data for the forcedchoice task were collected. That not all participants carried out both tasks, as well as the differences between informants' background as we described in Section 5.1, do not provide ideal conditions for a study and we are aware of its limits, as already pointed out. However, the data we collected still allows us 
to make some remarks on the nature and the distribution of SCLs in heritage Friulian.

\subsubsection{The Forced-Choice Task}

The forced-choice task consisted of 24 items. Eight items targeted ScLs, but only four will be reported here, because the others are not relevant to the questions asked in this study. ${ }^{7}$ Sixteen items targeted other constructions such as differential object marking. Participants had to choose between two proposed sentences, one with and one without a SCL. The order of the two sentences was counterbalanced across the task. The aim of the task was to test whether clitics are still agreement markers in heritage Friulian or whether they are analyzed as pronouns. The tested contexts are:

(i) doubling of a pronominal or lexical subject

(14) Maria *(e) à comprât il pan.
Mary she.scL has bought the bread
'Mary bought bread.'

(ii) doubling of a topicalized subject

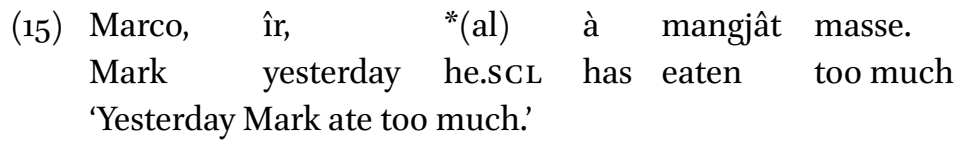

(iii) cluster of SCLs with other clitic elements (negation, direct and indirect object, reflexive, impersonal).
(16) Un sarpint, îr,
(*al) lu à copât.
a snake yesterday he.SCL it.OCL has killed 'Yesterday he killed a snake.'

(iv) repetition of the SCL in both conjuncts in coordinated structures
(17) $\mathrm{Al}$
mangje e *(al) bef.
he.SCL eats and he.SCL drinks.
'He is eating and drinking.'

Participants were presented with auditory stimuli recorded by a Friulian native speaker. Each recorded item contained a pair of sentences testing one of the phenomena in i-iv; after listening to the sentences, participants were asked to choose the one they preferred. It is well known that a forced-choice task does

7 Data were excluded when a speaker did not give a clear answer for a particular item. 
not bring about conclusive evidence regarding the speakers' grammar, all the more for HL speakers who generally express less straightforward acceptability judgments (see Polinsky, 2018, 2020). For this reason, we cross-checked these data with spontaneous production.

\subsubsection{Spontaneous Production}

In the production task, informants were asked to tell a short story about their past. In the case of first-generation immigrants, the interviewer asked the informants to say something about the experience of arriving at the destination country; in the case of HSs, the interviewer asked the informants to say something about their childhood. In this way, we managed to obtain a uniform corpus of spontaneous speech containing several sentences both in the present and the past tense.

Spontaneous production was used to support elicited data in the questionnaire and to test whether the use of clitics depended also on other linguistic or non-linguistic features.

\section{$6 \quad$ Results}

\section{1 $\quad$ Forced-Choice Task}

The forced-choice task confirmed our expectation that clitics are undergoing a process of reanalysis as pronouns ${ }^{8}$ as shown in Tables $3^{-6}$ : SCLs in items marked with an asterisk $\left({ }^{*}\right)$ display a pronominal behavior and are not grammatical in Friulian as described in previous studies on this variety. This is particularly evident in the context of doubling, which is lost in most cases. Table 3 shows that both G1 and Hs s disfavor the doubling of a non-topicalized subject (through the use of the clitic $e$ in sentence 18). As stated above, Friulian as described in grammars would show clitic doubling in these contexts. The only grammatical way to utter these sentences in Friulian should be the one in Example (18).

Table 3 shows that most of our informants chose the version without a subject clitic, which is not grammatical in Friulian. ${ }^{9}$

8 A statistical analysis of these data is not possible due to the low number of sentences.

9 A reviewer points out that the possibility of dropping the SCL in doubling contexts is expected for pronouns, as we showed in Section 4 for Brazilian Portuguese. Recall, however, that Friulian SCLs should not be dropped in this context: as agreement markers, they are always obligatory and do not distinguish between topicalized and non-topicalized DP subjects. 


(18) Maria e à comprât il pan. o/4
$\begin{aligned} & \text { Mary she.scL has bought the bread } \\ & \text { (19) *Maria à comprât il pan. }\end{aligned}$
$\begin{aligned} & \text { Mary has bought the bread } \\ & \text { 'Mary bought bread.' }\end{aligned}$
Total

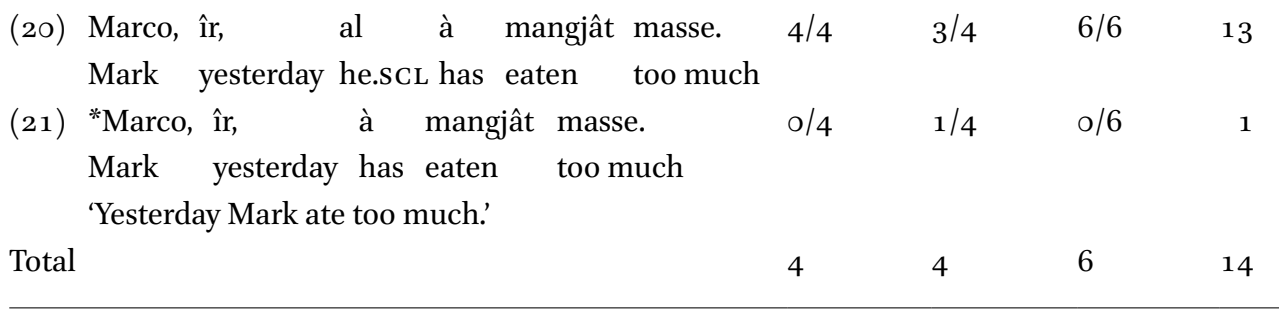

In topicalization contexts, such as in Table 4 , the picture is different: topicalized subjects are doubled in most cases, as expected in Friulian.

Most participants accepted the doubling of topicalized subjects (20), with only one HS in Argentina preferring the sentence without the SCL (21). This suggests that, in sentences with a lexical subject, topicalization is the context in which SCLs are most likely to appear. This is reminiscent of the situation in Standard French and colloquial Brazilian Portuguese, in which a subject pronoun can double a topicalized subject.

The restriction imposed on the realization of SCL s in clusters, which has been described for Friulian as spoken in Italy, is generally lost in Hs s in Argentina and Brazil (22), while it seems stable in G1 speakers in Argentina (23).

In the context of coordinated structures, we see that first-generation speakers normally accept the repetition of the clitic in both conjuncts (24), as shown in previous studies on Friulian. Hss, on the other hand, seem to allow for an optional realization of the clitic in the second conjunct (24). 
G1 (AR) HS (AR) HS (BR) Total

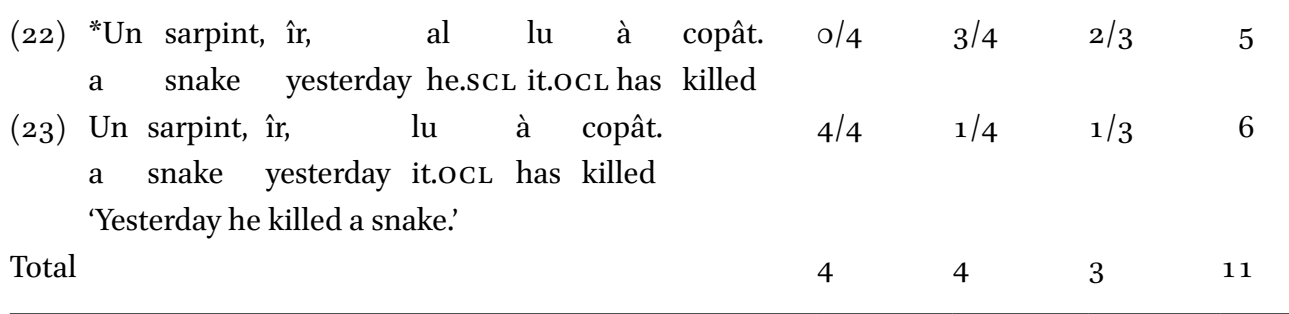

TABLE 6 Realization of SCLS in coordinated structures

\begin{tabular}{llllll}
\hline & & G1 (AR) & HS (AR) & HS (BR) & Total \\
\hline $\begin{array}{l}\text { (24) Al mangje e al bef. } \\
\text { he.scL eats and he.scL drinks }\end{array}$ & $4 / 4$ & $2 / 4$ & $5 / 6$ & 11 \\
$\begin{array}{l}(25) * A l \quad \text { mangje e bef. } \\
\text { he.sCL eats and drinks } \\
\text { 'He is eating and drinking. }\end{array}$ & $0 / 4$ & $2 / 4$ & $1 / 6$ & 3 \\
Total & 4 & 4 & 6 & 14 \\
\hline
\end{tabular}

Table 6 shows that most informants chose the expected structure with a subject clitic in each coordinated conjunct. However, two Hs s in Argentina and one in Brazil chose the structure with only one subject clitic. Recall that this should not be possible in Friulian: subject clitics are obligatorily realized every time a finite verb appears.

The data presented in Tables $3^{-6}$ confirm that Friulian SCLs in Argentina and Brazil are changing from inflectional to pronominal elements.

\subsection{Spontaneous Production Data}

For the spontaneous production data, all sentences containing finite verbs were coded for the following linguistic variables: person, subject type, cluster, verb class, and clause type. For the variable 'person,' 2nd person was excluded from the analysis. This was done for two reasons. First, in Friulian, 2nd person singular SCL s behave differently from 1st and 3 rd person in that they are unaffected by the constraints on clitic clusters described in Section 2: they are realized in 
all contexts and in the literature are generally treated differently from other SCL s. ${ }^{10}$ Second, there were too few instances of sentences with 2nd person singular and plural (only $6 \%$ of the data) to be able to include them in a statistical model. First person singular and plural, as well as 3rd person singular and plural, were merged into one category, as we did not observe significant differences within the same person and between singular and plural. For 'subject type,' a distinction was made between DP s (which included both demonstrative and full DP s), null subjects, pronouns and quantified pronouns, ${ }^{11}$ but the latter category was excluded due to the low number of cases (only nine). The variable 'cluster' refers to whether there was some other intervening clitic (such as a negator, a direct or indirect object, a reflexive or an impersonal clitic), in which case an SCL is not expected according to previous studies on Friulian. The variable 'verb class' consisted in three categories, namely transitive/unergative, unaccusative/passive and copular constructions, and the variable 'clause type' distinguished between matrix clauses and subordinate clauses. ${ }^{12}$

We also coded each sentence for whether there was a continuation or a shift in topic. If the referent of the SCL was the subject of the previous sentence, the sentence was coded as Topic Continuation; otherwise, if the referent was not the subject of the previous sentence (including the cases of reintroduction of an old referent after some time and introduction of a totally new referent), the sentence was coded as Topic Shift (see also De Prada Pérez, 2009). Topic continuation is an important factor that determines pronoun use in canonical null subject languages (Frascarelli, 2006; Frascarelli \& Hinterhölzl, 2007; Jiménez-Fernández, 2016; Sorace, 2009). If scLs in Argentinian and Brazilian

$10 \quad$ According to Renzi and Vanelli (1983) and Vanelli (1998), second person singular needs a different treatment from other subject clitics. As a matter of fact, it is the only person that is realized in all cases and in all varieties. In Poletto's (2000) analysis of various subject clitics, second person singular occupies a special HearerP position, the lowest one in the clitic field that she proposes. We leave the investigation on and person for future research.

11 Besides Friulian, our study targeted other heritage northern Italo-Romance varieties, such as Venetan, Trentino and Piedmontese, which were not included in this article. Some of these homeland varieties, in particular the Venetan ones, exhibit a different distribution of subject clitics with lexical, pronominal and quantified subjects (see Benincà, 1994). Friulian subject clitics behave more regularly in this respect, as they double all types of subjects. All the varieties were uniformly tested for the same varieties, even though we would not expect a difference in the doubling of various subjects in Friulian.

12 As in the case of subject type, the literature on Friulian subject clitics does not show evidence of a different distribution with different verb or clause types. These variables were nevertheless included in the analysis, as they have been proved relevant in the realization of subject clitics in other varieties in our study. See in particular Benincà (1994), Manzini and Savoia (2005) and Poletto (2000) for a discussion on the realization of subject clitics in relative clauses and unaccusative constructions with postverbal subjects. 
Friulian indeed behave like pronouns, we may expect them to obey a similar discourse constraint.

In total, 58 o sentences were coded, of which 375 contained an SCL and 205 did not. Two generalized mixed effects models were run using the lme4 package (Bates et al., 2012) from statistical tool R (R Development Core Team, 2017). The first model included all the data and the second model included only sentences with null subjects, as this context is crucial to determine whether the SCL is analyzed as a pronoun or an agreement marker.

In both models, all variables mentioned above (person, subject type, cluster, verb class, clause type and topic) were included, as well as the variable 'group', for which orthogonal sum-to-zero contrasts were set; one contrast compared the G1 speakers to all HSs, and the other compared the two HS s groups in the different countries with each other. The two-way interactions between group and all other factors were also entered into the models.

The first model, which included all subject types, rendered a significant effect of group, which was modulated by interaction effects with some of the other variables. For instance, a significant interaction between group and clus$\operatorname{ter}(\beta=1.91, \mathrm{SE}=0.68, \mathrm{t}=2.8 \mathrm{o}, \mathrm{p}=.005)$ and subsequent Tukey posthoc tests showed that only in sentences with no other intervening clitics, G1 speakers were significantly more likely to produce SCLs (26) than the Argentinian HSs $(27),(p<.001)$ as well as more than the Brazilian Hs s $(p=.01)$. In sentences containing clitic clusters there was no difference between the three groups: all participants tended to drop the SCL. This is illustrated in Figure 1.

(26) Buenos Aires (Argentina, G1)

Gno pari al veve une vore diamis.

my father he.sCL had a lot of friends

'My father had a lot of friends.'

(27) Buenos Aires (Argentina, Hs)

Gno fi à viodut una femina.

my son has seen a woman

'My son saw a woman.'

Similar effects were found in the model which included only null subjects. A significant interaction between group and cluster $(\beta=-2.84, \mathrm{SE}=0.90, \mathrm{t}=-3.15$, $\mathrm{p}=.002$ ), followed up by Tukey post hoc tests, indicated that in null subject sentences without clusters, the G1 immigrants in Argentina were most likely to use an SCL, followed (with a significant difference; $\mathrm{p}=.016$ ) by the Brazilian HS, and the Argentinian HSs, who produced least SCLs of all, and significantly 


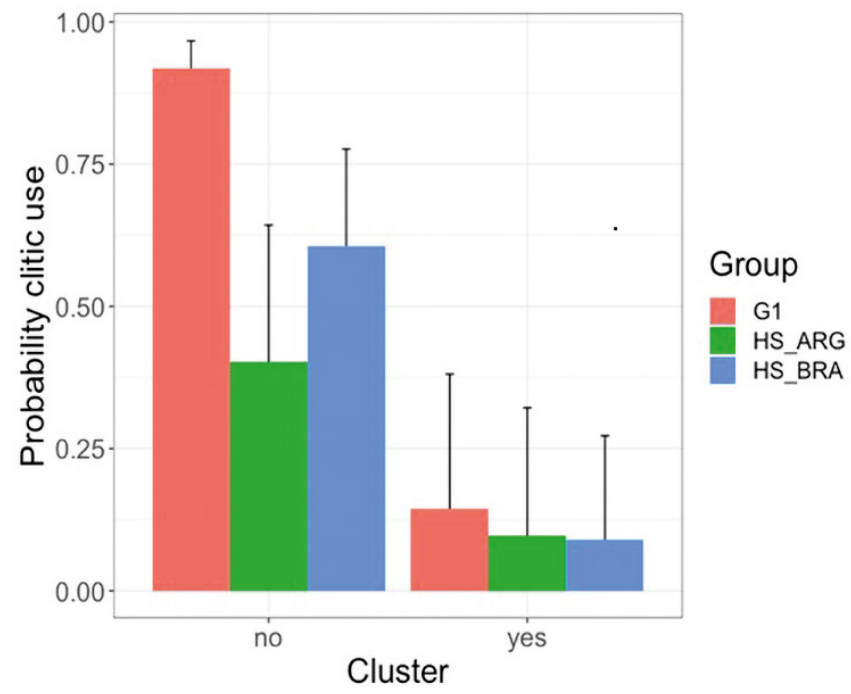

FIGURE 1 Differences in the realization of SCL $\mathrm{s}$ in clitic clusters

less than the $\mathrm{G1}(\mathrm{p}<.001)$, and marginally significantly less than the Brazilians HS s $(p=.07)$. Post hoc tests moreover indicated that only the immigrants and the Brazilian HS s were more likely to produce more SCLs in sentences without clusters (G1: p < .oo1; HS_Bra: $\mathrm{p}<$.001), but the Argentinian HS s did not differ significantly between sentences with and without clusters $(p=.19)$ These effects are shown in Figure 2.

The full model revealed another interaction effect, namely between group and person $(\beta=-1.42, \mathrm{SE}=0.69, \mathrm{t}=02.06, \mathrm{p}=.039)$, indicating that both $\mathrm{HS}$ groups were significantly more likely to produce clitics in the 3 rd person (28) than in the 1st person (29) ( $\mathrm{p}=0.001$ for the Argentinian HS s; 0.026 for the Brazilian HSs), while the first-generation did not make this distinction. This effect can be seen in Figure 3 .

(28) Ivorà (Brazil)

$\mathrm{Al}$ à fat une promese.

he.sCL has made a promise

'He made a promise.'

(29) Ivorà (Brazil)

Sin stats indaur.

are.1PL been behind

'We were left behind.' 


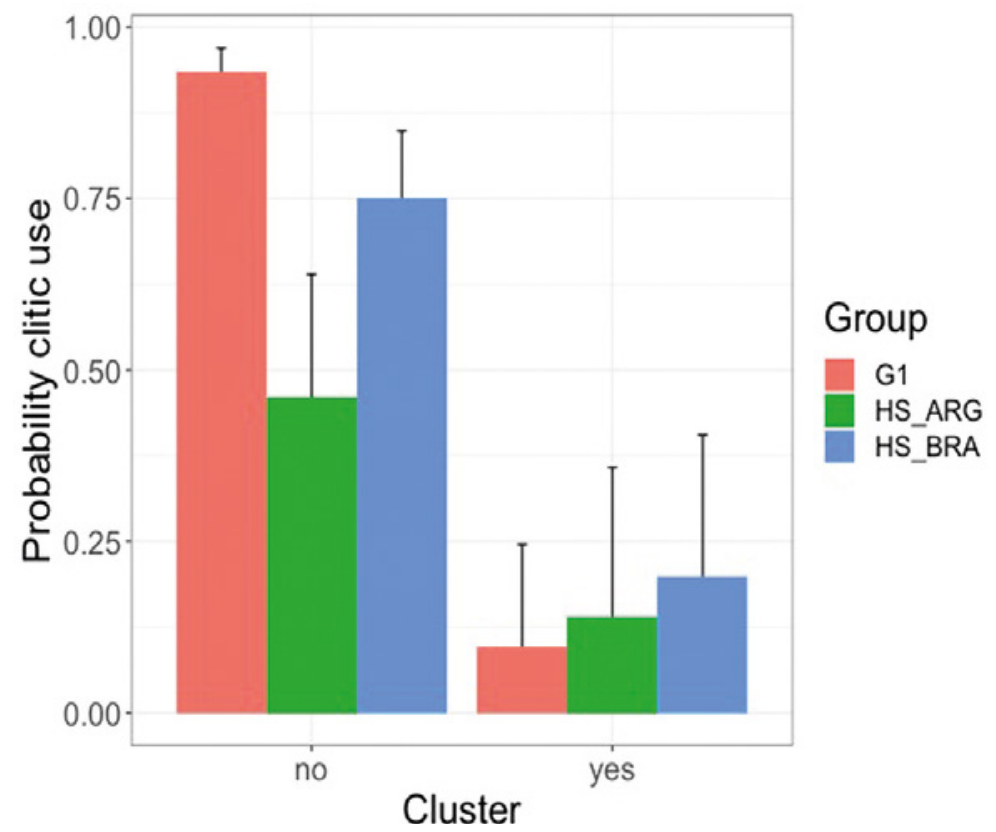

FIGURE 2 Differences in the realization of SCL $\mathrm{s}$ in clitic clusters in null subject contexts

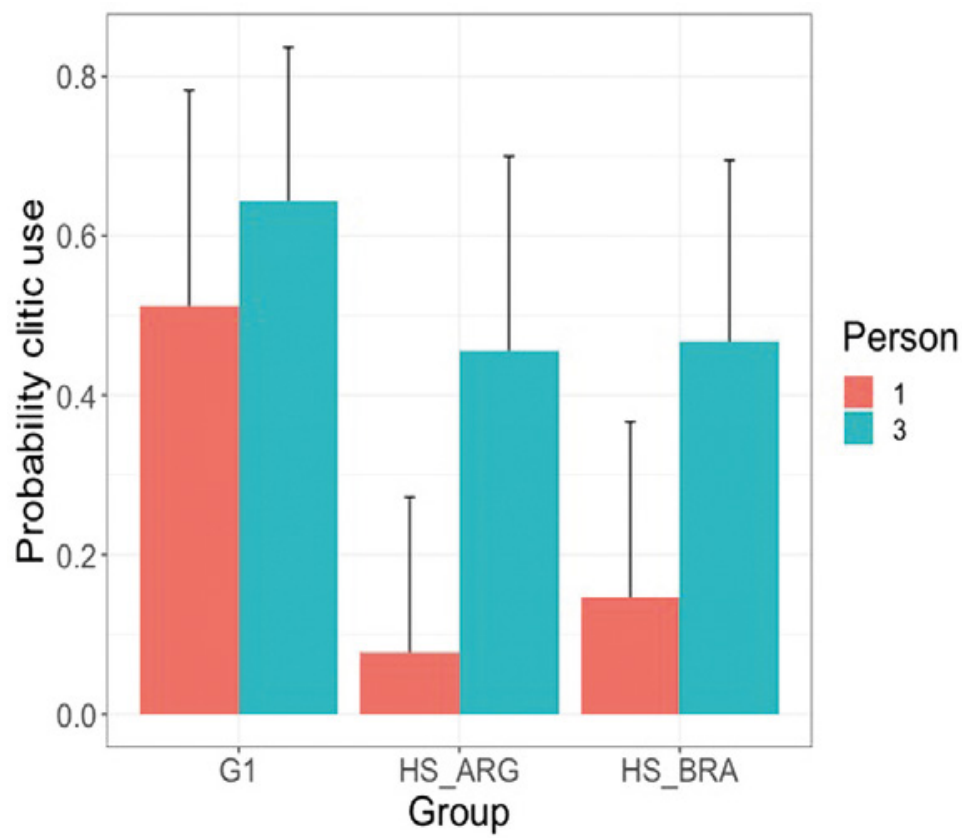

FIGURE 3 Interaction between group and person (1 and 3 ) in the realization of SCLS 


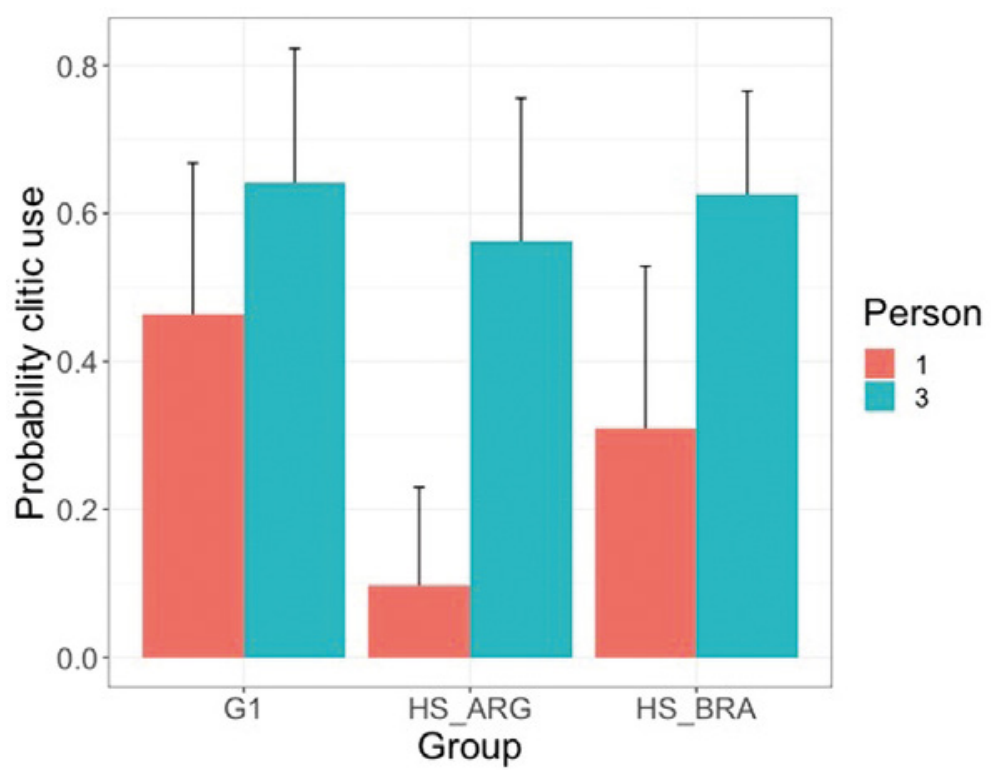

FIGURE 4 Interaction between group and person (1 and 3 ) in the realization of SCL $s$ in null subject contexts

As for the model on null subjects only, a significant main effect of person $(\beta=1.50, \mathrm{SE}=0.37, \mathrm{t}=4.04, \mathrm{p}<.001)$ was found there as well. While the interaction with group was not significant in this model, post hoc comparisons were carried out to check whether similar patterns could be found as in the model on the entire dataset. These showed that, in sentences with null subjects only, Brazilian Hs s did not differentiate significantly between the 1st and 3 rd person clitics $(\mathrm{p}=.12)$. Neither did the $\mathrm{G} 1(\mathrm{p}=.8 \mathrm{o})$, similar to the first model. The Argentinian Hs s on the other hand preferred SCL $s$ with 3 rd person in null subject sentences, just as they did in the model on all sentences. These effects are shown in Figure 4.

In the model on the entire dataset, subject type also had a significant effect on clitic use $(\beta=1.21, \mathrm{SE}=0.41, \mathrm{t}=2.90, \mathrm{p}=.004)$. Pairwise comparisons indicated that all speakers were significantly more likely to drop the SCL when it doubled a pronoun (30) than when it doubled a null subject $(31)(\beta=3.35$, $\mathrm{SE}=1.40, \mathrm{t}=2.90, \mathrm{p}=.01$ ), as shown in Figure 5 . The rate of dropped SCL $\mathrm{s}$ with lexical subject was between that of pronouns and null subjects, but the difference with each of the two extremes was not significant. This seems to indicate that the most appropriate context for these speakers to produce a SCL is when 


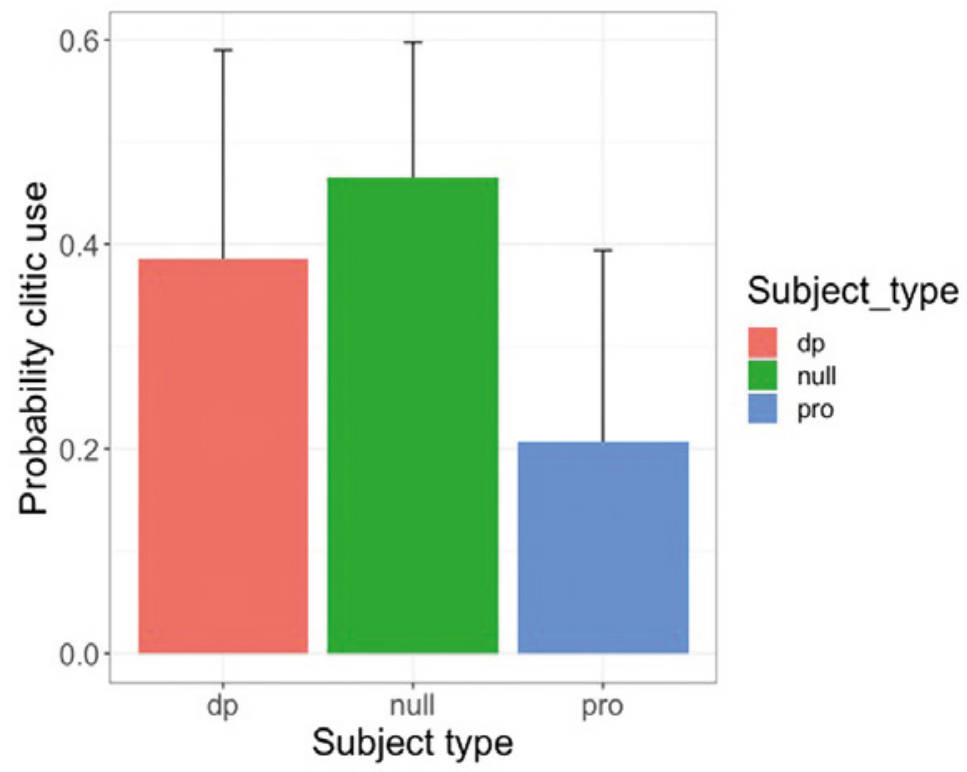

FIGURE 5 Realization of SCL s with different subject types (all speakers included)

there is an unexpressed subject and the least appropriate is when the clitic doubles an overt subject pronoun.

(30) Buenos Aires (Argentina)

Io soi tornat al gno mistir.

I am returned to=the my job

'I went back to work.'

(31) Buenos Aires (Argentina)

$\mathrm{O}$ soi tornat cà in Argentine.

I.SCL am returned here in Argentina.

'I came back to Argentina.'

Finally, the full model rendered a significant effect of topicality $(\beta=1.05$, $\mathrm{SE}=0.29, \mathrm{t}=3.64, \mathrm{p}<.001$ ), indicating a preference to produce a clitic when there was a shift in topic with respect to the previous sentence. The interaction with group was marginally significant as well $(\beta=-1.06, \mathrm{SE}=0.59, \mathrm{t}=-1.8 \mathrm{o}$, $\mathrm{p}=.07$ ), which led us to explore the comparisons through Tukey post hoc 


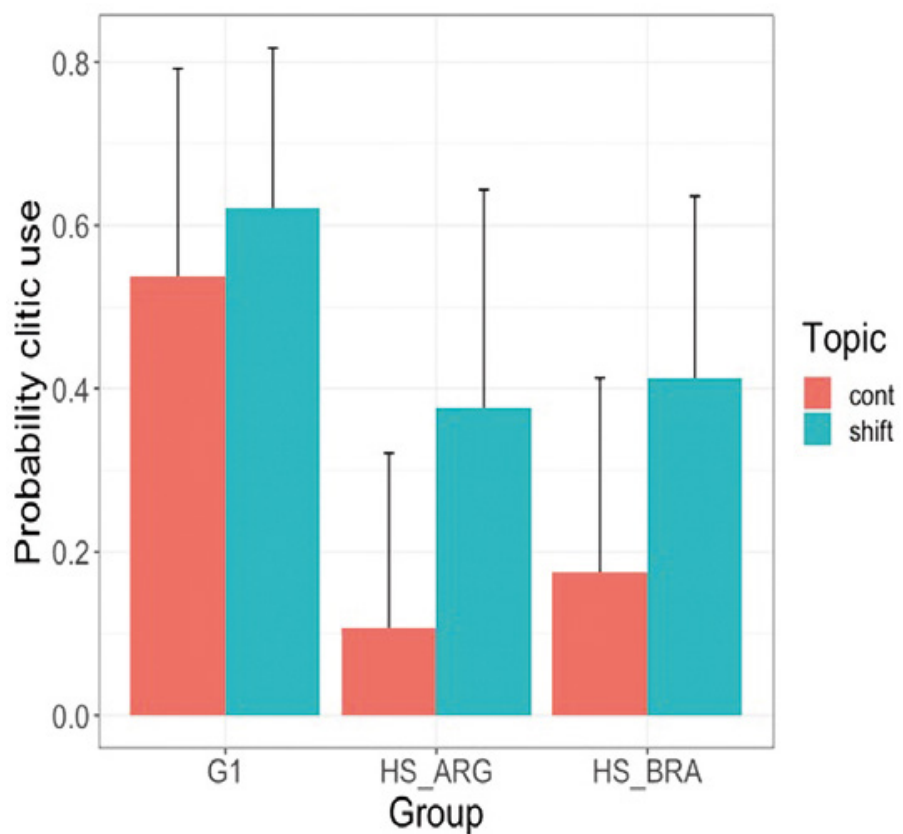

FIGURE 6 Effect of topicality (shift vs continuity) in the realization of SCLS

tests. These showed that, in fact, only the Argentinian HS s were significantly more likely to produce clitics in topic shift contexts than in topic continuation contexts (example 32) $(p=.02)$. For the Brazilian HSs, the same tendency was present, but the difference was not significant, $(\mathrm{p}=.10)$, and neither was the effect in the first-generation group $(\mathrm{p}=0.93)$. These effects are illustrated in Figure 6.

(32) Buenos Aires (Argentina)
a. Gno santul al
me
a dite: $[\ldots]$
my godfather he.sCL me.ocL has said

b. ShIFT I ai tacat fevelà in furlan, [...]

I.SCL have started to speak in Friulian

c. continuation [...] dop pro ai vut ancje la fortune di then pro have had too the fortune to sposà une fie di furlans. marry a daughter of Friulians

'My godfather told me: [...] . I started to speak Friulian, [...] then I was lucky enough to marry a Friulian descendent.' 


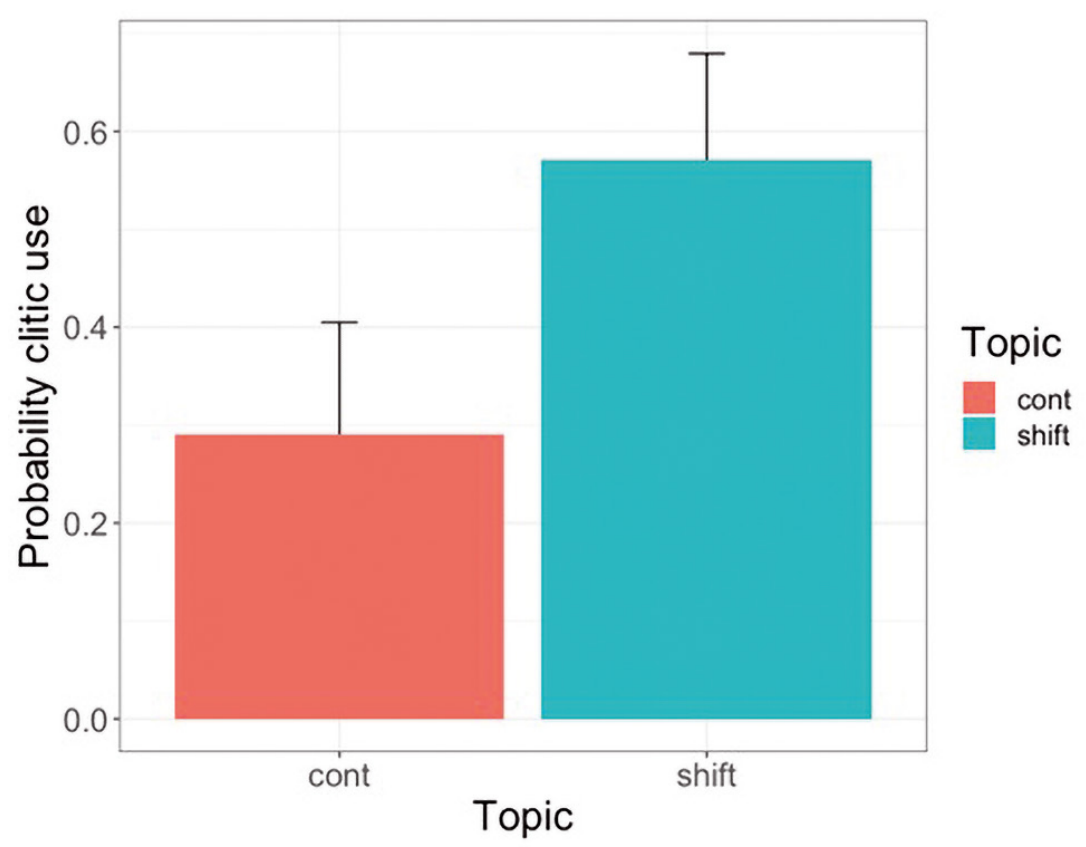

FIGURE 7 Effect of topicality (shift vs continuity) in the realization of SCL s in null subject contexts

The above-described effect of topicality on SCL use was found in all sentences.

The second model confirmed the significant effect of topicality for sentences with null subjects only $(\beta=1.17, \mathrm{SE}=0.34, \mathrm{t}=3.48, \mathrm{p}<.001)$, though it was not modulated by group. This means that in sentences with null subjects, all speakers, regardless of group, were more likely to produce a SCL in topic shift contexts than in topic continuation contexts with null subjects. The effect is illustrated in Figure 7 .

\section{Discussion}

The results of the forced-choice task presented in Section 6.1 indicate that SCLS in the varieties of Friulian spoken in Argentina and Brazil show a tendency towards reanalysis as pronouns. The tests (in particular the realization of the SCLs with topicalized and non-topicalized subjects and the repetition of the SCL in both conjuncts in coordinated structures) showed that SCLS allow also for a pronominal interpretation, which is not expected in Friulian as spoken in Italy. This situation resembles the results shown in Frasson (in press) for the heritage varieties of Venetan spoken in Brazil. However, sCLs are not dropped at random, as revealed by the spontaneous production data. 
One important syntactic factor that constrains the use of SCLs is person: 1st person SCLS are more likely to be dropped by HSs than 3 rd person subjects. Our data suggest that the peculiar contact situation in which heritage Friulian is spoken may have favored an acceleration of the process and the use of 1st person SCLs has therefore drastically declined in the span of one generation. ${ }^{13}$

The type of subject also influenced the likelihood of a subject to be omitted: most clitics were produced in sentences with null subjects, and the fewest in sentences with pronominal subjects. These findings further supports the notion that SCLs are indeed interpreted as pronominal elements: if the SCL is analyzed as a pronoun, it makes sense that it would be less felicitous in combination with another pronoun in the same sentence.

The spontaneous production data furthermore revealed an effect of the presence or absence of another clitic. In Friulian spoken in Italy, the presence of another clitic is the only context in which clitics can, and in fact should, be dropped. The data presented here show that both G1 immigrants and HSs seem to adhere to this constraint, perhaps unsurprisingly, given their general tendency to drop clitics in other contexts. However, the judgment data show a different picture when it comes to clitic clusters: while G1 immigrants correctly chose the sentence without the SCL, most HS s chose the sentence containing the SCL. It should be noted that the judgment task contained only one sentence with a clitic cluster, and therefore it would be appropriate to question whether this is truly representative of all sentences of this type. The critical sentence in the judgment task contained a null subject, and as we know from the production data, the type of subject influences the likelihood of a SCL to be produced. In fact, sentences with null subjects invoke the most frequent use of SCLs among HSs, compared to sentences with pronominal lexical subjects. However, a separate model on the spontaneous production data, which only included sentences with null subjects, showed a similar result: all three groups preferred to drop the SCL in the presence of another clitic. Discrepancies between judgment and production data are not uncommon in linguistic research, and especially in HS s (Bowles, 2011; Montrul, Foote, \& Perpiñán, 2008). The reason for this is probably that Hs s do not have much metalinguistic / explicit knowledge about their heritage language, given that

13 An anonymous reviewer pointed out that 1st and 2nd persons are 'stage topics' or 'permanently available topics,' i.e., pronouns whose referents are always available in the discourse (Erteschik-Shir, 2007). Therefore, if SCLs are turning into pronouns, they are expected to be subject to discourse properties, hence be dropped more for the ist and 2nd persons than for 3 rd. We agree with the reviewer that it may be easier to retrieve ist and 2nd persons in the discourse and thus the corresponding pronouns might be dropped more easily. 
they were never exposed to formal instruction in the language. Metalinguistic knowledge is particularly useful in tasks that target this type of explicit knowledge such as forced choice judgment tasks.

Finally, an important result that arose from the spontaneous speech data concerns the effect of topicality on SCL use. This finding regards the distribution of SCLs in the context of topic shift or continuity: SCLs are most likely to be dropped when the topic is the same as in the previous sentence. This means that SCLs, when used as pronouns, conform to conditions for the licensing of pro in line with what was shown by Frascarelli (2007), Miyagawa (2017) and Jimenez-Fernández (2016): they are most likely to be used in sentences in which there is a shift in the topic.

This finding is important in many respects. Firstly, it strengthens the idea that SCLs in heritage Friulian can be reanalyzed as pronominal elements: recall that Friulian SCLs have been described as obligatory agreement markers and topic distinctions should not be relevant to their realization. Secondly, it contradicts previous research showing that the syntax-discourse constraints are harder to master in bilinguals, as shown by the Interface Hypothesis. The second-generation HS s in our study introduced a new discourse-related condition on the realization of the reanalyzed SCLs, demonstrating a particular sensitivity to discourse factors, rather than a weakening or loss thereof. We would like to argue that this departure from other studies may be because most of them have considered bilinguals who speak one pro-drop language and one non-pro-drop language, the latter being English in most cases. In the present study, though, we are dealing with two pro-drop languages, which are typologically similar (see Rothman, $2010 \mathrm{ff}$. on the relevance of perceived typological similarity for transfer between contact languages). This distinction would explain why other studies on bilinguals speaking two Romance languages have also failed to identify problems with null subjects (Carvalho \& Child, 2011; De Souza, Chaves, \& Simioni, 2018; Rinke \& Flores, 2018): null subjects remain unaffected when two null-subject, typologically similar languages are in contact.

Further studies are necessary to establish whether the difference is due to the setting of the pro-drop parameter alone, or also the typological proximity between the two languages involved. The present study makes clear that that the predictions made by the IH do not work in the case of the language contact we analyzed.

Evidence that the contact languages play an important role is further provided by the differences observed between the HSs in Argentina and Brazil. One difference regarded the use of SCLs in clusters in sentences with null subjects. Although Hs s in Brazil and first-generation immigrants produced more SCLs in sentences without clitic clusters, in line with previous descriptions of 
Friulian, the Argentinian Hs s did not make this distinction. Moreover, the HS s in the two countries differ with respect to the effect of topicality. HS s of Friulian in Argentina clearly used ScLs in a way that is compatible with the conditions on the interpretation of pro we presented in section 1.2: SCLs are most likely to be dropped in sentences with no shift in the topic with respect to the previous topic. The same tendency was present in HS s of Friulian in Brazil but it did not reach statistical significance. Both these differences seem to suggest that HSs of Friulian in Argentina are in a further stage of a reanalysis process.

The most obvious explanation for this difference is the contact language, in particular the specific configuration of the contact language with respect to pro-drop. As briefly described in Section 2.2., Argentinian Spanish is considered a full-fledged pro-drop language, in which overt pronouns are used only in specific discourse contexts, such as when there is a shift in topic. Brazilian Portuguese, on the other hand, is typically described as a partial pro-drop language, which exhibits more overt subjects and in which the topicality effect is not as strong as in a pro-drop language like Argentinian Spanish.

However, other differences between the groups should be taken into account. Another possible factor behind the difference between Hss in Argentina and Brazil is the different generations to which the speakers belong. Our informants in Brazil are all third-generation HS s (they are the grandchildren of the original immigrants), as the migration wave to Brazil happened earlier than the one to Argentina, where all our informants are second generation HSs (the children of the original immigrants). This difference may account for the increased evidence of the topic continuity effects in second generation speakers in Argentina than in third generation speakers in Brazil. Second-generation speakers may introduce new interface conditions on the realization of the (reanalyzed) SCLs, but such conditions may be gradually lost in third generation speakers: the integration of information from syntax and discourse in the realization of SCLS requires a high processing load and is therefore recessive.

The two Hs groups also differed from each other in the amount of contact they had with the majority language. Hs s in Brazil live in isolated communities, farther away from big cities, which are still mainly composed of descendants of Friulian immigrants; as a result, they use their two languages in a diglossic fashion: Friulian is used with other members of the heritage community, while Brazilian Portuguese is normally used in all other contexts. HS s in Argentina (at least the ones in Buenos Aires), on the other hand, mix their two languages much more, using Spanish even with other Friulian speakers. This may result in a higher degree of cross-linguistic influence as a result of incomplete acquisition and/or attrition of the HL (e.g., Montrul, 2008). 
Finally, the heritage Friulian-Argentinian speakers' knowledge of Italian as a second language may have influenced the results. These speakers are trilingual, and their Friulian could have been influenced by two pro-drop languages, Spanish and Italian. This group's trilingualism may have enhanced the reanalysis of clitics as pronouns and their discourse-related behavior.

While the present study makes it impossible to differentiate conclusively between the possible effects of contact language, generation or other external factors (amount of contact with the majority language, knowledge of other languages), it contributes to the discussion on the importance of the specific language combination in bilingualism research.

\section{8}

\section{Conclusion}

The study described in this paper aimed to explore the use of SCLs in G1 immigrants and second and third generation HS s of Friulian in Argentina and Brazil. The data from a forced-choice task and a spontaneous production task revealed that SCLs in heritage Friulian are in the process of being reanalyzed as pronominal subjects, as they are no longer obligatory. Their dropping, however, is not random: it is constrained by various linguistic and extra-linguistic factors. For instance, 1st person clitics are dropped more often than 3 rd person clitics. Moreover, clitics are dropped more often when the topic of the sentence is the same as in the previous sentence, which is another reason to assume that these clitics are analyzed as pronominal elements. Discourse-constraints are not only not lost, but rather added to a domain that does not feature the same constraints in previously described varieties of Friulian, which indicates that the syntax-discourse interface is not always vulnerable in bilingual populations, as predicted by the Interface Hypothesis and as attested in previous work. We argue that a possible explanation for this departure from other studies might be that, unlike the majority of previous research, we have focused on closely related languages. This finding underlines the importance of expanding our research to include more language pairings, particularly typologically related languages.

\section{Acknowledgments}

This research received funding by the European Research Council under the Horizon 2020 Research and Innovation Programme (grant agreement CoG 681959_MicroContact). We would like to thank Jan Casalicchio and Francesco 
Maria Ciconte for the extensive data collection in Argentina and for the valuable discussion of our results; Marcos Zancan, Eduardo Valduga and Richard Dosso for the help with data collection in Brazil; Ernestina Dalla Corte and the Friulian Society of Buenos Aires for help with data collection in Argentina; Beatrice Bancheri for help with translation of the Friulian stimuli; and Piet van Tuijl for help with the statistical analysis.

\section{Notes on Contributors}

Alberto Frasson is a PhD student at Utrecht University. He graduated in Foreign Languages and Literatures from the University of Venice Ca' Foscari in 2016.

Roberta D'Alessandro is professor of Syntax and Language Variation at Utrecht University. She is the PI of the ERC-CoG Microcontact.

Her interests include syntactic microvariation, agreement, contact, auxiliary selection, and the syntax-PF interface.

Brechje van Osch is a postdoctoral researcher at the Arctic University of Norway (UiT). Her research interests include heritage language bilingualism, the vulnerability of linguistic interfaces and cross-linguistic influence.

\section{References}

Barbosa, P., Duarte, M., \& Kato, M. (2005). Null Subjects in European and Brazilian Portuguese. Journal of Portuguese Linguistics, 4(2), 11-52. https://doi.org/10.5334/ jpl.158.

Benincà, P. La variazione sintattica. [Syntactic variation]. Mulino.

Benincà, P., \& Vanelli, L. (2015). Morfologia e sintassi. [Morphology and syntax] In S. Heinemann \& L. Melchoir (eds.), Manuale di linguistica friulana. [Handbook of Friulian linguistics] (pp. 390-412). De Gruyter.

Benmamoun, E., Montrul, S., \& Polinsky, M. (2013). Heritage languages and their speakers: Opportunities and challenges for linguistics. Theoretical Linguistics, 39(3-4), 129-181. https://doi.org/10.1515/tl-2013-ooo9.

Bowles, M. A. (2011). Measuring implicit and explicit linguistic knowledge. Studies in Second Language Acquisition, 33(2), 247-71. https://doi.org/10.1017/ So272263110000756.

Brandi, L., \& Cordin, P. (1989). Two Italian dialects and the null subject parameter. In O. Jaeggli and K. J. Safir (eds.), The null subject parameter (pp. 111-142). Springer. 
Calabrese, A. (1986). Pronomina: Some properties of the Italian pronominal system. MIT Working Papers in Linguistics, 8, 1-46.

Calabrese, A., \& Pescarini, D. (2014). Clitic metathesis in the Friulian dialect of Forni di Sotto. Probus, 26(2), 75-308. https://doi.org/10.1515/probus-2014-oo1o.

Cardinaletti, A., \& Starke, M. (1999). The typology of structural deficiency: On the three grammatical classes. In H. van Riemsijk, (ed.), Clitics in the languages of Europe. (pp. 145-233). Mouton de Gruyter.

Carminati, M. N. (2002). The processing of Italian subject pronouns [doctoral dissertation], University of Massachusetts.

Carvalho, A., \& Child, M. (2011). Subject pronoun expression in a variety of Spanish in contact with Portuguese. In J. Michnowicz \& R. Dodsworth (eds.), Selected proceedings of the 5th Workshop on Spanish Sociolinguistics (pp. 14-25). Cascadilla Proceedings Project.

Carvalho, A., \& Bessett. R. (2015). Subject pronoun expression in Spanish in contact with Portuguese. In A. Carvalho, R. Orozco, and N. Shin (eds.), Subject pronoun expression in Spanish: A cross-dialectal perspective (pp. 143-165). Georgetown University Press.

Casalicchio, J., \& Masutti, V. (2015). A syntactic analysis of the subject clitic $a$ in the Friulian variety of Campone. Isogloss: Special issue on Italo-Romance morphosyntax, $103^{-132 .}$

Della Porta, G. (1922). Grammatica pratica della lingua friulana. [Practical grammar of the Friulian language] Del Bianco.

De Prada Pérez, A. (2009). Subject expression in Minorcan Spanish: Consequences of contact with Catalan [Doctoral dissertation], Pennsylvania State University.

De Souza, K., Chaves, \& L. Simioni. (2018). Sujeitos nulos no português de Poblado Uruguay. [Null subjects in the Portuguese of Poblado Uruguay] PAPIA, 28, 7-24. http://revistas.fflch.usp.br/papia/article/viewFile/3041/pdf.

Duarte, M. E. (1993). Do pronome nulo ao pronome pleno: a trajetória do sujeito no português do Brasil [From the null pronoun to the full pronoun: the subject's trajectory in Brazilian Portuguese]. In Roberts, I., \& Kato, M. (eds.), Português Brasileiro: Uma viagem diacrônica (Homenagem a Fernando Tarallo) [Brazilian Portuguese: A diachronic journey (Homage to Fernando Tarallo)] (pp. 107-128). Campinas.

Duarte, M. E. (1995). A perda do princípio evite pronome no português brasileiro. [The loss of the Avoid Pronoun Principle in Brazilian Portuguese] [Doctoral dissertation], University of Campinas.

Duarte, M. E. (2000). The loss of the 'avoid pronoun' principle in Brazilian Portuguese. In M. Kato, M., \& E. Negrão (eds.), Brazilian Portuguese and the null subject parameter (pp. 17-36). Vervuert.

Dubinina, I., \& Polinsky, M. (2013). Russian in the USA. In M. Moser, ed., Slavic Languages in Migration (pp. 2-29). Lit Verlag. 
Erteschik-Shir, N. (2007). Information structure: The syntax-discourse interface. Oxford University Press.

Filiaci, F., Sorace, A., \& Carreiras, M. (2014). Anaphoric biases of null and overt subjects in Italian and Spanish: A cross-linguistic comparison. Language, Cognition and Neuroscience, 29(7), 825-843. https://doi.org/10.108o/o169o965.2013.801502.

Flores, C., \& Rinke, E. (2020). Factors constraining subject expression in European Portuguese spoken in Hamburg: A bi-generational corpus investigation. Discours: Revue de linguistique, psycholinguistique et informatique [Discourse: A journal of linguistics, psycholinguistics and computational linguistics], 26, 3-31. https://doi .org/10.400o/discours.10648.

Frascarelli, M. "Subjects, Topics and the Interpretation of Referential Pro: An Interface Approach to the Linking of (Null) Pronouns." Natural Language \& Linguistic Theory, 25 (2007), 691-734. https://doi.org/10.1007/s11049-007-9025-x.

Frascarelli, M., \& Hinterhölzl, R. (2007). Types of topics in German and Italian. In K. Schwabe \& S. Winkler (eds.), On information structure, meaning and form (pp. 87-116). John Benjamins.

Frascarelli, M., \& Jiménez-Fernández, Á. L. (2019). Understanding partiality in pro-drop languages: An information-structure approach. Syntax, 22(2-3) (2019), 162-198. https://doi.org/10.1111/synt.12184.

Frasson, A. "Clitics are not enough: on agreement and null subjects in Brazilian Venetan." Linguistic Analysis, 43(1-2) (in press).

Gaglia, S. (2012). The Friulian subject clitics. In S. Gaglia \& M. Hinzelin, eds., Inflection and word formation in Romance languages (pp. 83-118). John Benjamins.

Guido Mendes, C., \& Iribarren, C. (2007). Fixação do parâmetro do sujeito nulo na aquisição do português europeu por hispanofalantes. [Fixation of the null subject parameter in the acquisition of European Portuguese by Spanish speakers]. In M. Lobo, M. \& M. A. Coutinho (eds.), XXII Encontro Nacional da Associação Portuguesa de Linguística: Textos seleccionados [22nd national conference of the Portuguese Linguistic Association: Selected texts] (pp. 483-497). Associação Portuguesa de Linguística.

Holmberg, A. (2005). Is there a little pro? Evidence from Finnish. Linguistic Inquiry, ${ }_{3} 6$, 533-564. https://doi.org/10.1162/oo2438905774464322.

Hulk, A., \& Müller, N. (2000). Bilingual first language acquisition at the interface between syntax and pragmatics. Bilingualism: Language and Cognition, 3(3), 22744. https://doi.org/10.1017/S1366728900ooo353.

Jiménez-Fernández, Á. L. "When Discourse Met Null Subjects." Borealis: An International Journal of Hispanic Linguistics, 5 (2) (2016), 173-189. https://doi .org/10.7557/1.5.2.3727.

Kato, M. (1999). Strong and weak pronominals in the null subject parameter. Probus, $n$, 1-37. https://doi.org/10.1515/prbs.1999.11.1.1. 
Keating, G., Vanpatten, B., \& Jegerski, J. (2011). Who was walking on the beach? Anaphora resolution in Spanish heritage speakers and adult second language learners." Studies in Second Language Acquisition, 33(2), 193-221.

Lozano, C. (2006). The development of the syntax-information structure interface: Greek learners of Spanish. In V. Torrens \& L. Escobar (eds.), The acquisition of syntax in Romance languages (pp. 374-399). John Benjamins.

Margaza, P., Bel, A. (2006). Null subjects at the syntax-pragmatics interface: Evidence from Spanish interlanguage of Greek speakers." In M. G. O'Brien, C. Shea, \& J. Archibald (eds.), Proceedings of the 8th Generative Approaches to Second Language Acquisition Conference (pp. 88-97). Agreement beyond phi (Cambridge: The MIT Press, 2017).

Montrul, S. (2004). Subject and object expression in Spanish heritage speakers: A case of morphosyntactic convergence. Bilingualism: Language and Cognition, 7(2), 125142. https://doi.org/10.1017/S1366728904001464.

Montrul, S. (2008). Incomplete acquisition in bilingualism: Re-examining the age factor. John Benjamins.

Montrul, S., Foote, R., \& Perpiñán, S. (2008). Gender agreement in adult second language learners and Spanish heritage speakers: The effects of age and context of acquisition. Language Learning, 58(3), 503-53. https://doi.org/10.1111/j.1467-9922.2008.00449.x.

Montrul, S. (2016). The acquisition of heritage languages. Cambridge University Press.

Nagy, N. G., Aghdasi, N., Denis, D., \& Motut, A. (2011). Null subjects in heritage languages: Contact effects in a cross-linguistic context. University of Pennsylvania Working Papers in Linguistics, 17(2), 134-144. https://repository.upenn.edu/cgi/ viewcontent.cgi? article $=1202 \&$ context $=$ pwpl.

Poletto, C. (1993). La sintassi del soggetto nei dialetti italiani settentrionali. [The syntax of subject in northern Italian dialects] Unipress.

Poletto, C. (2000). The higher functional field: Evidence from Northern Italian dialects. Oxford University Press.

Polinsky, M. (2018). Heritage languages and their speakers. Cambridge University Press.

Renzi, L., \& Vanelli, L. (1983). I pronomi soggetto in alcune varietà romanze [Subject pronouns in some Romance varieties]. In P. Beninca, M. Cortelazzo, A. Prosdocimi, L. Vanelli, and A. Zamboni, A. (eds.), Scritti linguistici in onore di G.B. Pellegrini [Linguistic writings in honor of G.B. Pellegrini] (pp. 25-35). Pacini.

Rinke, E., \& Flores, C. (2018). Another look at the interpretation of overt and null pronominal subjects in bilingual language acquisition: Heritage Portuguese in contact with German and Spanish. Glossa: A Journal of General Linguistics, 3(1), 1-24.

Rizzi, L. (1982). Issues in Italian syntax. Dordrecht.

Rizzi, L. (1986). On the status of subject clitics in Romance. In O. Jaeggli. \& C. SilvaCorvalan (eds.), Studies in Romance Linguistics (pp. 391-419). Dordrecht. 
Rodrigues, C. (2004). Impoverished morphology and A-movement out of case domains [Doctoral dissertation], University of Maryland.

Rothman, J., Pascual y Cabo, D., \& Lingwall Odio, A. (2012). Applying the interface hypothesis to heritage speaker (HS) acquisition: Evidence from Spanish mood. In A. K. Biller, A. K., Chung, E. Y. \& Kimball, A. E. (eds.), BUCLD 36: Proceedings of the 36 th annual Boston University Conference on Language Development (pp. 564-576). Cascadilla Press.

Schmitz, K., Di Venanzio, L., \& Scherger, A. (2016). Null and overt subjects in Italian and Spanish heritage speakers in Germany. Lingua, 180, 101-123. https://doi.org/10.1016/j .lingua.2016.04.004.

Serratrice, L. (2005). The role of discourse pragmatics in the acquisition of subjects in Italian. Applied Psycholinguistics, 26(3), 437-462. https://doi.org/10.1017 .So142716405०50241

Silva-Corvalán, C. (2001). Sociolingüística y pragmática del español [The Sociolinguistics and Pragmatics of Spanish]. Georgetown University Press.

Sorace, A. (2011). Pinning down the concept of 'interface' in bilingualism. Linguistic Approaches to Bilingualism, 1(1), 1-33. https://doi.org/10.1075/lab.1.1.o1sor.

Sorace, A., \& Filiaci, F. (2006). Anaphora resolution in near-native speakers of Italian. Second Language Research, 22(3), 339-368. https://doi.org/10.1191/o267658306sr2710a.

Sorace, A., \& Serratrice, L. (2009). Internal and external interfaces in bilingual language development: Beyond structural overlap. International Journal of Bilingualism, 13(2), 195-210. https://doi.org/10.1177/13670069o933981o.

Sorace, A., Serratrice, L., Filiaci, F., \& Baldo, M. (2009). Discourse conditions on subject pronoun realization: Testing the linguistic intuitions of older bilingual children. Lingua, 119(3), 46o-477. https://doi.org/10.1016/j.lingua.20o8.o9.oo8.

Tsimpli, I., Sorace, A., Heycock, C., \& Filiaci, F. (2004). First language attrition and syntactic subjects: A study of Greek and Italian near-native speakers of English. International Journal of Bilingualism, 8(3), 257-277. https://doi.org/10.1177/13670o6 9040080030601.

Vanelli, L. (1998). I dialetti italiani settentrionali nel panorama romanzo: Studi di sintassi e morfologia. [Northern Italian dialects in the Romance scenario: Studies of syntax and morphology]. Bulzoni. 